\title{
The Dualism of Modern Just War Theory
}

\section{Graham Parsons}

\section{Philosophia}

Philosophical Quarterly of Israel

\section{ISSN 0048-3893}

Volume 45

Number 2

Philosophia (2017) 45:751-771

DOI 10.1007/s11406-016-9790-z

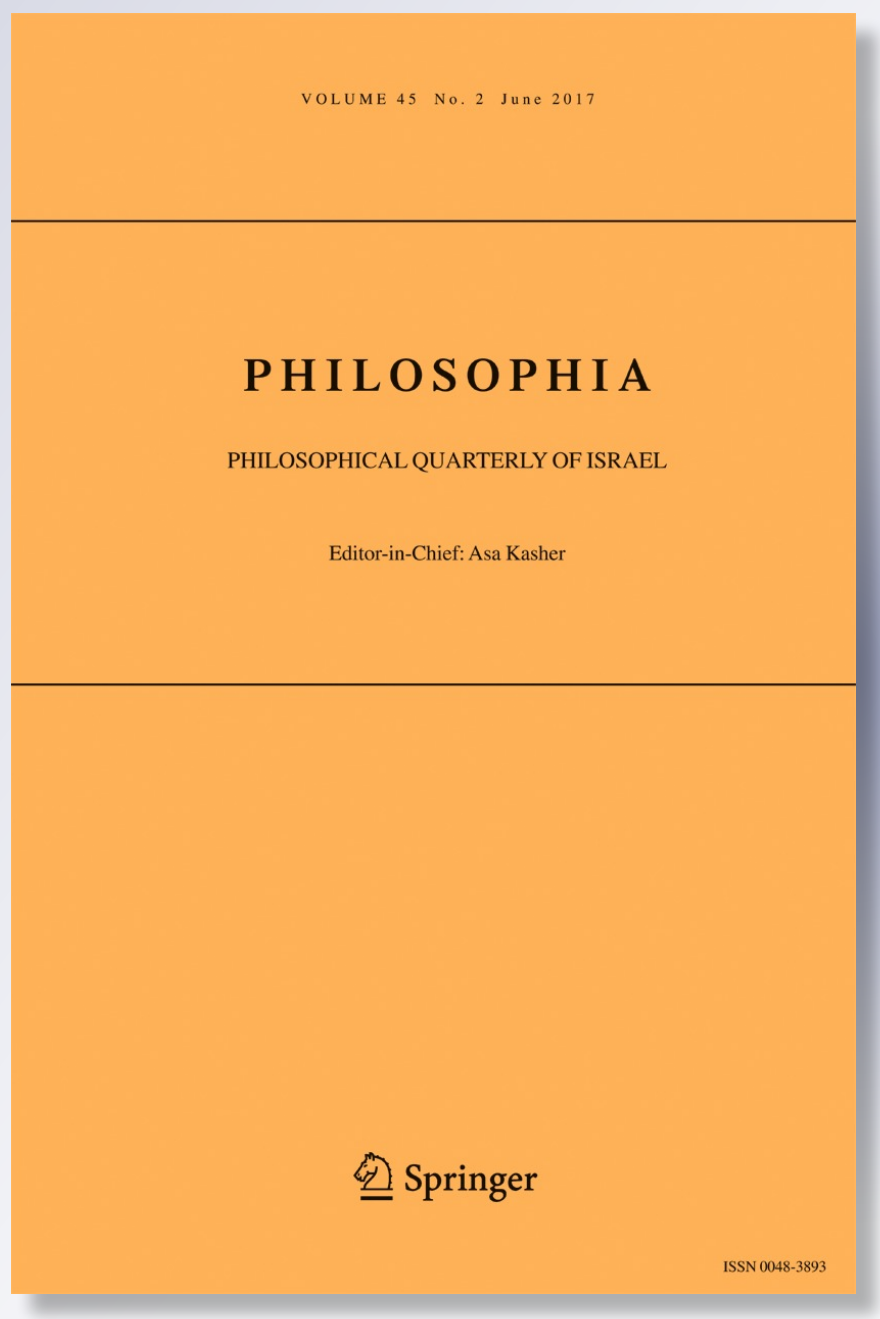

Springer 
Your article is protected by copyright and all rights are held exclusively by Springer Science +Business Media Dordrecht. This e-offprint is for personal use only and shall not be selfarchived in electronic repositories. If you wish to self-archive your article, please use the accepted manuscript version for posting on your own website. You may further deposit the accepted manuscript version in any repository, provided it is only made publicly available 12 months after official publication or later and provided acknowledgement is given to the original source of publication and a link is inserted to the published article on Springer's website. The link must be accompanied by the following text: "The final publication is available at link.springer.com". 


\title{
The Dualism of Modern Just War Theory
}

\author{
Graham Parsons ${ }^{1}$ (D)
}

Received: 20 November 2015 / Revised: 5 September 2016 / Accepted: 23 November 2016 /

Published online: 5 December 2016

(C) Springer Science+Business Media Dordrecht 2016

\begin{abstract}
Conventional modern just war theory is fundamentally incoherent. On the one hand, the theory contains a theory of public war wherein ethical responsibility for the justice of war belongs uniquely to political sovereigns while subjects, including soldiers, are obligated to serve in war upon the sovereign's command. On the other hand, the theory contains a theory of discrimination which presupposes that participants in war, including soldiers, are responsible for the justice of the wars they fight. Moreover, these two components are derived from two inconsistent visions of political justice. The theory of public war, it turns out, is derived from a theory of justice that places the value of political society conceived of as a supra-individual communal entity above the value of the private individual. The theory of discrimination, however, is derived from a theory of justice that places the value of the private individual above that of political society. This inconsistency is revealed by analyzing the theories of Vitoria, Grotius, and Walzer. Appreciating this problem also helps situate the recent revisionist critiques of conventional just war theory.
\end{abstract}

Keywords Public war - Discrimination - Vitoria - Grotius · Walzer · Revisionist just war theory

Michael Walzer (2006 [1977]) describes his just war theory as "dualist" (21). For him, the two basic categories of just war theory - the theory of jus ad bellum, justice of the resort to war, and the theory of jus in bello, justice of the conduct of war - are logically independent. There is no necessary connection between the justice of a war from the perspective of one category and its justice from the perspective of the other. An unjust war can be fought justly and vice versa.

Shortly after introducing the dualism of jus ad bellum/jus in bello, Walzer explains that it is derived from another, more fundamental, dualism (34-41). This deeper

Graham Parsons

graham.parsons@usma.edu

1 Department of English and Philosophy, United States Military Academy, West Point, 607 Cullum Road, West Point, NY 10996, USA 
dualism is a division of moral responsibility for the justice of war within political communities. For Walzer, the set of agents responsible for jus ad bellum is distinct from the set responsible for jus in bello. On his account, political leaders are uniquely responsible for waging war in accordance with jus ad bellum while the subordinates of these leaders, including soldiers, are obligated to obey their leader's commands. At the same time, political leaders and their soldiers are each responsible for waging war in accordance with jus in bello. In other words, only political leaders are bound by jus ad bellum while political leaders and soldiers are bound by jus in bello (see 38-9).

Walzer thus describes soldiers as occupants of two distinct moral roles in war. Walzer's view is that with respect to jus ad bellum soldiers are moral servants of their political leaders in that they are obligated to follow their leader's commands. When under orders, soldiers may justifiably obey commands that violate jus ad bellum requirements. At the same time, Walzer holds that soldiers are obligated to ensure that they never violate jus in bello requirements even when ordered to by their political leaders. In the conduct of war, soldiers may not justifiably obey commands contrary to justice. Thus, for Walzer, with respect to jus ad bellum soldiers are obligated to obey commands and with respect to jus in bello soldiers are not obligated to obey commands. ${ }^{1}$

An analysis of this dualism of responsibility and its history reveals something very disturbing about conventional modern just war theory: It is fundamentally incoherent. I hope to show that this dualism is based on two inconsistent components of just war theory that have simultaneously been defended by theorists throughout the modern period. On the one hand, there is a theory of public war wherein ethical responsibility for the justice of war belongs uniquely to political sovereigns while subjects, especially soldiers, are obligated to serve in war upon the sovereign's command. On the other hand there is a theory of discrimination wherein it is impermissible to target noncombatants while waging a just war yet it is permissible to target combatants. Though there is disagreement among theorists as to why combatants are to be treated differently than noncombatants, they are all committed to the view that soldiers are responsible for the justice of the wars they fight. These two components of just war theory are inconsistent in that they attribute to soldiers two conflicting moral roles in war. According to the theory of public war, soldiers are not responsible for the justice of the wars they fight. According to the theory of discrimination, soldiers are responsible for the justice of the wars they fight.

Understanding this conflict and its origins reveals the fundamental incoherence of modern just war theory. The theory of public war, it turns out, is derived from a theory of justice that places the value of political society conceived of as a supra-individual communal entity above the value of the private individual. Here, the soldier is conceived of as an ontological part of the political community. The theory of discrimination, however, is derived from a theory of justice that places the value of the private individual above that of political society. Here, combatants, including soldiers, are conceived of as ontologically independent beings. Modern systematic just war theory is thus based on two, inconsistent theories of justice and social ontologies - one strongly communitarian, the other individualist. In this way, modern systematic just war theory is dualist all the way down.

\footnotetext{
${ }^{1}$ On this general dualism of responsibility, see also Walzer (2004).
} 
Some commentators have noted a similar conflict within just war thought generally. David Rodin (2002), for instance, points out that the just war has been understood as either a relation between irreducibly social bodies or as a relation between individuals. Taking these options as logical possibilities, Rodin examines both alternatives, finding inadequacies in each. On my reading, the different frameworks do not just compete within the logical space of just war thought generally but in fact compete within the particular systematic theories of a number of seminal just war theorists in the modern period. Indeed, the two views manifest themselves at similar points in the work of each of these theorists. This suggests that the dualism of modern just war theory is a product of the particular presumptions and aims of modern theorists. ${ }^{2}$

Unlike Rodin, this paper does not seek to criticize or defend the alternative normative and ontological frameworks. Rather, I aim merely to pinpoint the origins of these competing frameworks, thereby explaining the confusion and enabling us to better understand our current situation in order to make wiser philosophical choices. In particular, understanding the dualism of modern just war theory sheds new light on the nature and significance of recent revisionist theories of just war.

The paper is divided into three parts. The first part analyses the theories of Francisco Vitoria, Hugo Grotius, and Walzer to reveal the inconsistencies between their theories of public war and theories of discrimination. The second part analyzes the origins of the inconsistencies in the same theories to reveal inconsistent foundational commitments regarding the nature of justice and the individual/community relation. The third part attempts to explain this dualism of modern just war theory. ${ }^{3}$

\section{The Dualism of Public War and Discrimination}

A dualism of responsibility similar to Walzer's has pervaded just war theory throughout the modern period. Although its earlier incarnations were never explicitly acknowledged let alone purported to be coherent, political subjects, especially soldiers, have been understood to have two distinct sets of moral responsibilities in war. On the one hand, soldiers are the instruments of their political communities who are obligated to serve in war upon command provided the war is not patently unjust. On the other hand, soldiers are never obligated to serve in war upon command and are responsible for the justice of any war they participate in.

\subsection{Vitoria}

I trace this dualism as far back as the early sixteenth century work of Francisco Vitoria. Vitoria argues that typical subjects are not morally required to examine the reasons

\footnotetext{
${ }^{2}$ Stephen Neff (2005: 111-3) also finds a dualism in modern just war theory. For him, the theory is dualist in that it has commitments to rules that are based on natural law and rules that are based on the voluntary law of nations. Modern just war theory juggles both, sometimes prioritizing natural law, sometimes prioritizing the law of nations. Though I sense an interesting relation between this dualism and my topic, a discussion of it is beyond the scope of this paper.

${ }^{3}$ I should note that Vitoria, Grotius, and Walzer are not the only theorists to exhibit this dualism. I would argue that the views of Francisco Suarez (2015 [1621]) are also an example.
} 
behind the sovereign's decision to wage and declare war. Concern with such matters is simply not part of the subject's civic responsibility. Rather, this responsibility is solely the sovereign's as well as anyone the sovereign asks for assistance in examining the matter. Aside from other high ranking officials and those who counsel the sovereign, "lesser subjects who are not invited to be heard in the councils of the prince nor in public council are not required to examine the causes of war, but may lawfully go to war trusting the judgment of their superiors" (1991: 308).

This division of responsibility between the sovereign and the subject over the decision to wage war means that the subject's moral duties in war are not relative only to the justice of the war itself, but are relative primarily to the commands of his sovereign. The subject's overriding duty is to obey orders to serve in wars declared by his legitimate prince. Such orders bind a subject independent of the justice of the war he is being ordered to participate in. The subject's primary moral concern should not be with the justice of the war he is asked to participate in but with the legitimacy of the authority from which the order to participate is issued.

In cases where a subject has reason to doubt the justice of his sovereign's war, he is still obligated to serve because obedience to legitimate authority is an independent moral duty. To think otherwise is to assume that, "If I am in doubt whether the prince's war is just or whether the cause of a particular war is just, it follows immediately that I must doubt whether or not I may lawfully fight." But, Vitoria argues,

I admit that it is never lawful to act against a conscientious doubt, so that if I am in doubt whether I should act or not it is a sin to act. But it is incorrect to deduce that if I am in doubt as to whether the cause of war is just, I must therefore doubt whether I may lawfully make war, or fight in that war. In fact, we must deduce just the opposite: if I am in doubt about the justice of war, it follows that it is lawful for me to go to war at the command of my prince. In the same way, if an officer of the law is in doubt whether the judge's sentence is just, it is quite invalid to conclude that he must doubt whether he may lawfully carry out that sentence; on the contrary, indeed, he knows very well that he is required to carry out the sentence of his superior. (312)

This is not to say that for Vitoria subjects are always obligated to obey commands by their legitimate sovereign to serve in war. In cases where the subject finds the sovereign's war to be patently unjust, that is, when the war is unjustified on its face, subjects are not only permitted to not serve but are obligated not to (307-8). For Vitoria, to participate in a war that one is convinced is unjust is to act in bad faith and is always wrong.

But, again, if there is any doubt as to whether a war is just or not, subjects remain obligated to serve when ordered to by their legitimate authorities (312). This, coupled with Vitoria's insistence that subjects are not required to examine the justification of a war they are ordered to participate in and that sovereigns ought not to explain and justify their wars to the public (308), means that most participants in wars waged and declared by legitimate authorities are not merely innocent. In fact, they are doing what is morally required of them. In these cases, anything less than obedience would be wrong. Only in cases where a war is patently unjust do subjects who participate have anything to account for. In all other cases, subjects are acting in accordance with their 
duties. The injustice of a war, therefore, does not necessarily taint its participants in any way.

At the same time as Vitoria asserts this view of the responsibilities of soldiers, he also maintains that soldiers are always responsible for the justice of the wars they fight. For Vitoria, a soldier fighting in an unjust war is not innocent of the injustice of the war even if he was ordered to fight by his legitimate political sovereign and the order was not patently unjust.

This alternative view of the responsibilities of soldiers is implicit in Vitoria's theory of discrimination. Vitoria argues that it is permissible to deliberately kill soldiers in war yet impermissible to deliberately kill noncombatants. He claims that in the course of a just war, it is permissible to indiscriminately kill the combatants on the opposing side (319) and to execute those combatants even after the war is over (320). However, he maintains that noncombatants ought never to be deliberately killed (314-5). ${ }^{4}$

Crucially, Vitoria argues that what makes it impermissible to deliberately kill noncombatants is that they are innocent, whereas what makes it permissible to deliberately kill combatants, including soldiers, in an unjust war is that they are not innocent. For Vitoria, it is always wrong to deliberately kill the innocent (314-5). Vitoria is not here employing an idiosyncratic view of "innocence" but is using it to mean, roughly, not morally responsible. ${ }^{5}$ The non-innocent in war are those who have done wrong by participating in an unjust war. Vitoria clearly distinguishes the innocent and the non-innocent in war on moral grounds, referring to the noninnocent as "wicked." Moreover, Vitoria takes his principle of discrimination to apply to both just defensive and punitive wars. For Vitoria, just as it would be wrong to punish a person for a crime he is not responsible for, so too would it be wrong to defend oneself by deliberately injuring a person who is not morally responsible for the threat one is attempting to thwart (282-3).

But if soldiers are not innocent of the injustice of a war even when they are following the orders of their legitimate political sovereign, then it must be Vitoria's view that soldiers are responsible for the justice of the wars they fight and they are obligated to not participate in unjust wars regardless of the commands of their sovereign. The moral distinction between soldiers fighting in an unjust war and noncombatants is based on the view that soldiers are responsible for their participation in war. For Vitoria, if a soldier serves in an unjust war, even when under orders to do so, he is personally acting unjustly and thereby becomes a legitimate target of deliberate violence.

In this way, Vitoria has two views of the distribution of responsibility for the justice of war at work in his theory. On one hand, soldiers are not responsible for the justice of war and are obligated to serve in war upon the command of their legitimate political sovereign. On the other hand, soldiers are responsible for the justice of the wars they participate in and serving in an unjust war makes them liable to deliberate attack. These two views of combatant responsibilities are entailed by his theory of authority over war and his theory of discrimination in war respectively. ${ }^{6}$

\footnotetext{
${ }^{4}$ Still, Vitoria permits "plundering" and enslaving noncombatants (317-9).

${ }^{5}$ Contrary to the contention of Johnson (1975: 196).

${ }^{6}$ It is likely that this inconsistency is behind Vitoria's ambiguous account of the "invincibly ignorant" soldier in an unjust war as both justified in and excused for fighting (see 313).
} 


\subsection{Grotius}

Roughly a century after Vitoria, we can find the same conflicting accounts of the responsibilities of soldiers in the work of Hugo Grotius. Grotius defends what he calls "public war." Public war is war that is waged by a public body under the legitimate authority of a political sovereign. The participants in public war are soldiers who act as moral instruments of their sovereign. Participants in public war are thus not private, autonomous actors but moral servants of a political authority.

Grotius distinguishes between principals, assistants, and instruments in war (2005 [1625]). Principals, assistants, and instruments are each possible efficient causes of war. However, the respective moral status of these efficient causes in war varies.

The principal is the interested party or parties that act with the authority to make war. They are the interested party or parties who engage in war willingly and claim the authority to do so without the approval of any higher authority. In a private war, those who are not the interested party but come to the aid of a principal as private persons, whether as kin, neighbors, fellow private citizens, benefactors, or allies, are not the principal of the war but act as assistants. These assistants, as private agents in private wars, are morally responsible for their decision to participate in war.

In public war, by contrast, the principal is the supreme civil power. It is the civil power that is the interested party and who acts with full authority to engage in war. In a public war, those who participate as subjects of their supreme civil power are instruments, not assistants. The political subject in war acts as a member of a public body and under the authority and direction of a political sovereign. Though subjects in war act by their own will, their will, in this case, depends on the will of their sovereign whom sets the subjects in motion with morally binding commands. As instruments of their civil power, they act under the obligation to obey the commands of their sovereign in things pertaining to war. As he says, "As a Servant is in a Family, the same is a Subject in a State, and is therefore the Instrument of the Sovereign...Nor can we doubt, but all Subjects may naturally be employed in War..." (386).

It is clear that, for Grotius, political subjects in war have the duty to obey the orders of their political sovereign to participate in war despite the fact that doing so puts their lives and limbs at stake. Grotius says clearly that in such cases subjects are morally obligated to act in ways that are contrary to their basic private interests. He says explicitly that it is a soldier's duty to remain at his post even under the hazard of death (357). And when the defense of a political society requires the use of a subject as a soldier, it is wrong for the subject to simply "quit the service of his country" (555).

Moreover, Grotius consistently compares political subjects to slaves (1167). He says that the civil power has "the greatest Power over its Members" (552). The civil power has the right to command subjects in order to cultivate their virtue, not merely to ensure they avoid violating the rights of others (357 and 1135). And, in all this, the civil power has the right to lie to subjects when it thinks the deception of subjects is necessary for the common good (1218-20).

This all implies that, for Grotius, political subjects ordered into war by their political sovereign are not morally responsible for the justice of the wars they participate in. Subjects can participate in an unjust war yet be doing what they are obligated to do.

At the same time, however, Grotius defends a principle of discrimination in defensive war that is based on the view that soldiers are responsible for the justice of their 
wars. Like Vitoria, Grotius defends a principle of discrimination that prohibits deliberately attacking noncombatants and permits deliberately attacking combatants when one is waging a just defensive war. $^{7}$

The reason Grotius holds that combatants on the opposing side in a defensive war may be deliberately attacked while noncombatants may not is that the combatants are personally acting wrongly in the relevant way while noncombatants are not. For Grotius, by taking up arms and joining in an unjust war, combatants act wrongly. The injustice that their public body commits against others by engaging in unjust aggression is something that they, as participants in that aggression, have each personally committed. Though soldiers may be excused from blame, the wrong that their public commits in an aggressive war is a wrong that is attributable, at least in some measure, to all its combatants. This renders combatants in an unjust war liable to deliberate attack. ${ }^{8}$ However, noncombatants, in a public body that commits aggression cannot have that wrong attributed to them. As noncombatants, the aggression their community commits is not something they personally commit. Unlike combatants, noncombatants have personally acted in accordance with natural right in the relevant respect and there can be no just cause for war against them.

Grotius argues repeatedly that subjects of legitimate political authorities ought not to participate in unjust wars that their sovereign wages and orders them to participate in (1176-9). ${ }^{9}$ Subjects should not obey their sovereign's commands when there is doubt about the justification of those commands. Subjects should only obey when their sovereign's war is certainly justified. Thus, for Grotius, any soldier who participates in an unjust public war acts contrary to his moral duties. Any combatant in an unjust public war is personally acting unjustly.

It is for this reason that Grotius explicitly denies the possibility of the moral equality of combatants, that is, the possibility of soldiers on opposing sides of a public war confronting each other as equally morally innocent (1175-6). Contrary to Vitoria, who held that in a war between commonwealths, though both sides cannot have just cause for war, the soldiers on both sides can share the same moral status as equally obedient political subjects (1991: 321), Grotius says such a thing is not possible. For Grotius, the soldiers on the side without just cause will always have a different moral status than the soldiers on the side with just cause. This is because soldiers should only participate in just wars and should refuse to participate in unjust wars regardless of the commands of their sovereign. A soldier fighting in an unjust public war is personally acting unjustly while a soldier fighting in a just war is personally acting justly.

Thus, Grotius has two distinct views of the responsibilities of soldiers in war. On the one hand, they are not responsible for the justice of the wars they participate in. On the other, they are so responsible. These two views are found in his theory of public war and his theory of discrimination respectively.

\footnotetext{
${ }^{7}$ I speak here solely of Grotius' theory of discrimination in just war for defense against injury. Grotius also allows for war for the punishment of injury and the recovery of property. In these cases, what constitutes just discrimination in war is different from what it is in defensive war.

${ }^{8}$ For a similar reading of Grotius on this point, see Tadashi (1993).

9 A position that "surprised" Emer Vattel (2008 [1758]: 588).
} 


\subsection{Walzer $^{10}$}

Unlike Vitoria and Grotius, Walzer, as we have seen, acknowledges the dualist character of his theory. For Walzer, the fact that soldiers are not responsible for the justice of war and are responsible for the justice of war is not inconsistent. According to him, soldiers' responsibilities differ relative to the aspect of the justice of war in question. In particular, soldiers are not responsible for jus ad bellum, whereas they are responsible for jus in bello.

However, when we examine the basis of this dualism of responsibility, we find that it relies on an inconsistency that is similar to that in Vitoria and Grotius. Walzer's two conceptions of the soldier's responsibilities are derived from two inconsistent components of his theory of war. Like Vitoria and Grotius, Walzer posits a theory of public war wherein soldiers are obligated to obey their political leaders in war and a theory of discrimination wherein soldiers are not obligated to obey their leaders.

Contrary to how many commentators have understood him (see Mapel (1998), McMahan (1994 and 2009) and McPherson (2004)), ${ }^{11}$ Walzer argues that soldiers are not responsible for the justice of the wars they participate in because soldiers are obligated to serve in war upon command. This reading of Walzer is suggested by his discussion of the obligations of Erwin Rommel in WWII. For Walzer, Rommel was not responsible for the fact that the German war effort was unjust because of "the nature of political obedience. Rommel was a servant, not a ruler, of the German state; he did not choose the wars he fought but, like Prince Andrey, served his 'Tsar and country'...[B]y and large we don't blame a soldier, even a general, who fights for his own government. $\mathrm{He}$ is not the member of a robber band, a willful wrongdoer, but a loyal and obedient subject and citizen" (2006: 39).

Walzer describes war as "morally as well as physically coercive [my emphasis]" from the perspective of soldiers (53). Soldiers are not only physically and epistemically constrained by their governments. Provided there is a sufficient "fit" between their government and people, soldiers are also morally bound to serve their governments in war when ordered to. Soldiers, unlike mercenaries, have "a legal obligation and patriotic duty" to serve in war upon command (28). When a soldier fights, "We assume that his commitment is to the safety of his country, that he fights only when it is threatened, and that then he has to fight (he has been "put to it"): it is his duty and not a free choice" (27). It is this feature of public war that Walzer refers to as "the tyranny of war." As he says, we can understand aggression "as the exercise of tyrannical power, first over [the aggressor's] own people and then, through the mediation of the opposing state's recruitment and conscription offices, over the people they have attacked" (31). "Hence the peculiar horror of war: it is a social practice in which force is used by and against men as loyal or constrained members of states and not as individuals who choose their own enterprises and activities" (30).

Walzer develops a theory of discrimination in war that, like Vitoria and Grotius, permits deliberately attacking combatants but prohibits deliberately targeting

\footnotetext{
${ }^{10}$ My reading of Walzer here is drawn from Parsons (2012).

${ }^{11}$ Each of these authors fails to appreciate the centrality of the soldier's duty of serve in war upon command to Walzer's theory. They interpret Walzer as holding that soldiers are merely excused from blame for participating in an unjust war.
} 
noncombatants. Walzer argues that what makes combatants legitimate targets is that they are not innocent, while what makes noncombatants illegitimate targets is that they are innocent. Unlike Vitoria and Grotius, however, Walzer here employs a notion of "innocence" that is indifferent to the moral justifiability of or blameworthiness for the individual's actions in war. For Walzer, what makes a combatant in war not innocent and thereby liable to deliberate attack is that the combatant has taken up arms and is, rightly or wrongly, currently threatening others. It is irrelevant to the combatant's status as a legitimate target whether or not the war he or she wages is justifiable. Combatants as such render themselves liable to attack. As Walzer says, "simply by fighting, whatever their private hopes and intentions, [combatants] have lost their title to life and liberty, and they have lost it even though, unlike aggressor states, they have committed no crime" (136). ${ }^{12}$

For this reason Walzer cannot be accused of developing a theory of public war and a theory of discrimination that contradict each other in precisely the same way as do Vitoria and Grotius. Contrary to Vitoria and Grotius, Walzer does not hold that soldiers in an unjust war are liable to attack because they are responsible for the justice of the war they fight. Still, Walzer's theory of discrimination ultimately contradicts his theory of public war on the issue of the responsibilities of soldiers.

As we noted at the start, for Walzer, responsibility for abiding by the principle of discrimination belongs to soldiers as well as to their leaders. No one can permissibly violate the duty not to deliberately kill a person who has not forfeited their right to life. This holds even when one is ordered to engage in such killing by one's legitimate authority. The duty to not kill the innocent trumps all political obligations. This is why states may not override the principle of discrimination even when it would aid the progress of an otherwise just war and why soldiers are obligated to refuse to obey orders that violate the principle of discrimination (40, 304-16).

Here we see Walzer's assertion of two distributions of moral responsibility for the justice of war. According to Walzer's theory of public war, soldiers are obligated to obey orders even when those orders are to do something that violates justice. According to the theory of discrimination, soldiers are obligated to disobey orders that violate justice. The two theories thus hold soldiers responsible for the justice of their wars and not responsible for their wars.

It is tempting to try to reconcile these positions by reasserting Walzer's dualism of jus ad bellum/jus in bello. That is, we might think these distributions of responsibility are consistent because they are distributions of two different things. Soldiers are not responsible for jus ad bellum and are obligated to obey orders to participate in war whereas soldiers are responsible for jus in bello and are obligated to disobey unjust orders in the course of war. Admittedly, this is how Walzer sometimes presents his views.

But this won't solve the problem. This is because, first, the dualism of jus ad bellum/ jus in bello is supposed to be derived from the dualism of soldier's responsibilities. As Walzer argues clearly in a number of places, the reason we can take jus ad bellum and jus in bello to be logically independent is that there is a division of responsibility among the members of political communities for jus ad bellum and jus in bello. An unjust war

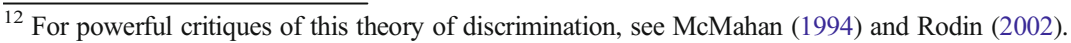


can be fought justly because political leaders and not soldiers are responsible for jus ad bellum while political leaders and soldiers share responsibility for jus in bello.

This is the ultimate point of his discussion of the responsibilities of Erwin Rommel. Walzer aims to explain how Rommel's participation in the war could be praiseworthy despite the clearly aggressive character of the German war effort. That is, he aims to explain the logical independence of jus ad bellum/jus in bello. He explains:

We draw a line between the war itself, for which soldiers are not responsible, and the conduct of war, for which they are responsible, at least within their own sphere of activity...We draw [the line] by recognizing the nature of political obedience. Rommel was a servant, not a ruler, of the German state; he did not choose the war he fought but, like Prince Andrew, served his "tsar and country'...[B]y and large we don't blame a soldier, even a general, who fights for his own government. He is not the member of a robber band, a willful wrongdoer, but a loyal and obedient subject and citizen... We allow him to say what an English soldier says in Shakespeare's Henry V: "We know enough if we know we are the king's men. Our obedience to the king wipes the crime of it out of us." Not that his obedience can never be criminal: for when he violates the rules of war, superior orders are no defense. The atrocities he commits are his own; the war is not. [The war] is conceived, both in international law and in ordinary moral judgment, as the king's business - a matter of state policy, not of individual volition, except when the individual is the king. (38-9)

Walzer reiterates the same point at the start of his discussion of the theory of jus in bello at the beginning of Part Three of the book. He says, "In our judgments of the fighting [jus in bello], we abstract from all consideration of the justice of the cause. We do this because the moral status of individual soldiers on both sides is very much the same: they are led to fight by their loyalty to their own states and by their lawful obedience" (127). Because of this status of soldiers with respect to jus ad bellum, we must judge wars with respect to jus in bello "without reference to the justice of their cause." That is to say, because of the division of responsibility for jus ad bellum and jus in bello there is a logical independence of jus ad bellum and jus in bello. Therefore, the dualism of soldier's responsibilities cannot then depend on the dualism of jus ad bellum/jus in bello as the above suggestion would have it.

Moreover, despite his assertion of their logical independence, both jus ad bellum and jus in bello are supposed to have the same basis in the individual rights to life and liberty. According to Walzer's account, what permits or prohibits war and discrete acts of war are one and the same set of human rights (xxiii-xxiv, 53, 54, 108, 135). ${ }^{13}$ To violate the principles of jus ad bellum is, most fundamentally, to violate the rights of people to life and liberty. To violate the principles of jus in bello is, most fundamentally, to violate the rights of people to life and liberty. Thus, for Walzer to say that soldiers are not responsible for jus ad bellum and are responsible for jus in bello would seem to commit him to the view that soldiers are not responsible for human rights violations and are responsible for human rights violations. In other words, for Walzer, soldiers are

\footnotetext{
$\overline{{ }^{13} \text { Walzer also reiterates this view }}$ of the basis of his just war theory in Spheres of Justice (1983: xv).
} 
obligated to obey commands that violate justice and soldiers are not obligated to obey commands that violate justice. Ultimately, Walzer's assertion of a logical distinction between jus ad bellum and jus in bello lacks any coherent justification and is the product of the fundamental incoherence of his thought examined below.

\section{The Dualism of Modern Just War Theory}

An examination of the origins of the conflict between public war and discrimination exemplified in Vitoria, Grotius, and Walzer, reveals an even more disturbing problem for this tradition. The theory of public war is based on the view that the preservation of the rights of the political community is the supreme concern in war and that the individual may be used and sacrificed for the sake of the community. This view relies on the conception of the political community as a supra-individual body whose members are its ontological parts. The theory of discrimination is based on the view that the rights of private individuals are the supreme concern in war and individuals may not be used and sacrificed for the sake of the community. This view relies on the conception of the individual as ontologically independent of the community. In other words, the theory of public war entails communitarian presumptions while the theory of discrimination entails individualist presumptions. In this way, conventional modern just war theory has dualist foundations.

The origins of the rights of public war can be found in pre-modern quasi-Aristotelian Scholastic political theories that hold the good of the supra-individual political community is paramount and that the duties of individuals are to do what is constitutive of or promotes the good of the community. ${ }^{14}$ On this point of view, the political community is, or is analogous to, a natural body and the individual is, or is analogous to, its part, something that only exists and flourishes in its relation to the whole. When it comes to soldiers, these theorists can thus conceive of them as essentially instruments of the political community and its ruler, bound to obey commands to serve in war largely independently of the justice of those commands and regardless of the personal sacrifice service in war requires.

This approach is evident in Aquinas who endorses the Aristotelian view of the commonwealth as analogous to a natural body, or a 'perfect community,' that is more than the sum of its individual parts. This supra-individual body has interests that cannot be reduced to the private interests of its parts. As he says, '[I]ndividual interests and the common good are not the same. Individuals differ as to their private interests, but are united with respect to the common good...' (2002: 7). For Aquinas, the common good can trump the private good.

Just as one man is part of a household, so a household is part of a State; and a State is a perfect community, as is said at Politics I. And so just as the good of one man is not the final end, but is subordinated to the common good, so too the good

\footnotetext{
${ }^{14}$ Some commentators see classical just war theory as individualist in nature (see Neff (2005: 56-7) and McMahan (2010a and 2010b)). For a rebuttal of these interpretations and a defense of the position taken here see Parsons (2013).
} 
of one household is subordinated to the good of the whole State, which is a perfect community. (82)

Aquinas holds that the authority to govern the parts of the commonwealth for the sake of common good is naturally vested in a ruler. Obedience to this ruler is the virtue of the subject and is good in itself (60). It is a soldier's purpose in the commonwealth to wage war when called upon by his legitimate king. Armies are raised by kings for the purpose of protecting the commonwealth against attack upon command. In this respect, soldiers qua soldiers are parts of the community that are to be used by the rulers for the sake of the preservation of the communal whole. This is grounded in the natural order of things.

For we observe that the part naturally exposes itself in order to safeguard the whole; as, for instance, the hand is without deliberation exposed to the blow for the whole body's safety. And since reason imitates nature, we find the same imitation among the political virtues; for it belongs to the virtuous citizen to expose himself to the danger of death for the conservation of the whole body politic... (1997: 563)

\subsection{Vitoria}

Vitoria is a thoroughgoing Thomist and this is evident in his just war theory. Like Aquinas, Vitoria characterizes the commonwealth as a supra-individual entity. In $\mathrm{On}$ the Law of War, shortly after asserting the right of the commonwealth to wage war, he defines the commonwealth in Aristotelian terms as 'a perfect community.' A perfect community, for him, is that in which 'nothing is lacking' and is 'complete in itself' (1991: 301)

Vitoria's sermon On Civil Power expresses this view of the commonwealth even more clearly. Relying heavily on Aristotle, he describes commonwealths and civil power as natural to mankind (6-10). He describes the commonwealth as an ontological whole which has rights that are foundationally distinct from the rights of private individuals. For him, the supreme value of justice is the common good, not the private good. Individuals are parts of the communal whole and may be used for the sake of the whole. Thus, he argues, soldiers may be used and sacrificed for the sake of the commonwealth. As he says,

[E]very man has the power and right of self-defense by natural law, since nothing can be more natural than to repel force with force. Therefore the commonwealth, in which 'we, being many, are one body, and every one member one of another' as the Apostle says (Rom. 12:5), ought not to lack the power and right which individual men assume or have over their bodies, to command the single limbs for the convenience and use of the whole. Individuals may even risk the loss of a limb if this is necessary to the safety of the rest of the body; and there is no reason why the commonwealth should not have the same power to compel and coerce its members as if they were its limbs for the utility and safety of the common good. (11) 
This view of the commonwealth and justice underpins Vitoria's theory of public war and his view that soldiers are obligated to obey commands to serve in war and are not obligated to ensure that the wars they participate in are just. The theory of public war originates in this pre-modern quasi-Aristotelian theory of justice wherein the interests of the supra-individual political community are prior to the interests of the private individual.

Vitoria's theory of discrimination must have a different basis. Recall, the theory of discrimination is based on the view that soldiers are not obligated to obey orders by their legitimate sovereign to participate in war. Rather, they are obligated to ensure that they only participate in just wars and are responsible for the justice of the wars they serve in. This puts them in a decidedly different moral position than does the theory of public war.

Vitoria's theory of discrimination does not clearly articulate the theory of justice it is based upon. However, it is reasonable to read the theory as based on an individualist theory of justice. In particular, the theory of discrimination appears to be based on a theory of just violence between private individuals. It appears to be an assertion of the private rights of self-defense that Vitoria embraces alongside the public rights of commonwealths to defense and punishment. On this theory, all individuals have the right to engage in violence and, in turn, the responsibility to ensure that their exercise of this right is just. Here, everyone shares responsibility for their violence and there is no entity with unique authority over war (299). When one person unjustly violates another, the victim has the right to protect his rights with violence directed against the attacker because the attacker has personally committed an injustice. In this case, the attacker is not an instrument of a higher authority but a private person with responsibility for his conduct.

But this theory conflicts with the theory of public war in that it posits a conflicting vision of the duties of subjects in war. The theory of public war requires denying subjects the private rights of self-defense. The "limbs" of the commonwealth cannot have rights to preserve themselves that trump the rights of the commonwealth.

In this way Vitoria's theory of just war juggles two inconsistent theories of justice. On the one hand he defends a theory of public war by appeal to the supremacy of the commonwealth as a supra-individual entity. On the other hand he defends a theory of discrimination by appeal to the supremacy of the individual and his rights of self-defense.

\subsection{Grotius}

Grotius' dualism has a different ultimate origin. At times, the basis of Grotius' theory of public war appears very similar to Vitoria's and the pre-modern theorists. He depicts the public body as a supra-individual entity and the member of the body as its part to be used for the sake of the whole. In his discussion of the nature of the principalinstrument relation he links the possibility of such relations to an essential ontological connection between the principal and the instrument.

By Instruments, we mean not Arms, nor such like Things; but certain Persons who act by their own Will, but yet so as that their Will depends on another, that sets it in Motion: Such is a Son to his Father, being part of himself naturally; or a 
Servant, as a Part of his Master by Law. For as a Part is not only a Part of the Whole, in the same Relation as a Whole is the whole of a Part, but that very Thing which it is, because of the Whole on which it depends: So the Thing possessed makes in some Manner part of the Possessor...As a Servant is in a Family, the same is a Subject in a State, and is therefore the Instrument of the Sovereign.

Nor can we doubt, but all Subjects may naturally be employed in War... (2005: 386)

But what makes Grotius fundamentally different from Vitoria and the classical theorists is that this understanding of the public body and the sovereign-subject relationship does not originate in nature. Rather, for Grotius the public body and the duty of the member to serve the body as an instrument have their origin in the social contract that founds the political community. Grotius is arguably the first systematic moral and political philosopher in the modern period to abandon the Aristotelianism of the pre-moderns and defend political obligations by appeal to a contract made out of self-interest by rights-bearing private individuals in a state of nature. ${ }^{15}$ For Grotius, civil right, or political justice, is not a component of natural right but a product of the exercise of voluntary right (162).

According to Grotius, individuals have certain private rights by nature. Among these is the authority to defend individuals from violations of their rights and the right to punish violators of rights without permission from anyone else (184-5). Though individuals have the right to engage in defensive or punitive violence it is their personal responsibility to ensure that it is done justly. Thus, by nature there is only private war, not public war.

Individuals find it more desirable to relinquish this private authority to enforce rights than to keep it and voluntarily constitute a political body, giving the majority the unique right to enforce justice on its members. This sovereign power of the political body also has the right to command the members to participate in the violent enforcement of justice. The purpose of the political association is to protect the individual rights that its members have by nature $(162,184,358)$. Grotius' view, similar to subsequent early modern social contract theorists, is that the only way to more effectively protect individual rights than can be done in the state of nature is to create legitimate institutions of public war wherein a sovereign power has the authority to decide when violence is appropriate and the right to command others to the engage in that violence.

The institutions of public war allow the civil power to legitimately command the members to serve in war regardless of the justice of the war and regardless of the personal peril the war puts the member in. The soldier, for Grotius, no longer has the natural right to use violence to enforce justice but is subject to the will of the sovereign. This is what it means to be the instrument of a principal with the right to wage war.

But this defense of public war is not consistent. The rights individuals are supposed to have by nature, including the right to engage in violence and, correlatively, the

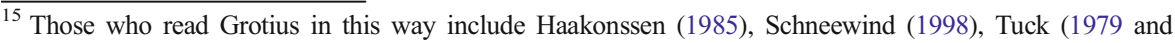
1999).
} 
responsibility for the just use of violence, cannot be alienated by contract. This is especially true if the contract that is supposed to alienate those rights is entered into specifically to protect those rights. Thus, on Grotius' theory when the sovereign orders a subject into war the subject should be responsible for ensuring that the war is just and ought to refuse to participate in unjust wars. If a subject should participate in an unjust war, even when following orders from his legitimate sovereign, he is acting unjustly.

In fact, as we have seen, Grotius repeatedly asserts precisely this view. For Grotius, no one is permitted to violate natural right even those who have voluntarily submitted to the authority of another. This is the view he relies on to support his theory of discrimination. What makes it permissible to deliberately attack soldiers engaged in an unjust war but not noncombatants is that the soldiers, by engaging in an unjust war, are personally acting unjustly whereas noncombatants are not.

Grotius' failure to coherently defend public war mirrors Hobbes' failure to coherently defend the rights of the sovereign. Hobbes argues that subjects give up the natural right to do whatever is necessary to preserve themselves and are absolutely bound to obey the sovereign (1994 [1651]: 110-8). Yet he argues that subjects always maintain the right to disobey any order that threatens their lives (141-3). This inconsistency is a result of the inability of his social contract to justify the alienation of the original rights of people. If political society is not natural but merely voluntary, natural rights must always limit the authority of the state. ${ }^{16}$ And since all people are said by Hobbes to have the natural right to do what is necessary to preserve their lives, the sovereign cannot use them as mere violent instruments. In Grotius' case too, this is why people cannot alienate the natural obligation to respect natural rights and become the instrument of the sovereign.

This explains Grotius' dualism. Grotius defends his theory of public war with a theory of justice that in fact undermines public war. As a result of this, Grotius' theory of public war asserts two inconsistent views of the obligations of soldiers in war. According to Grotius' theory of public war, soldiers are obligated to obey their sovereign and not obligated to obey their sovereign; they are instruments of their sovereign and not instruments of their sovereign. In defense of his theory of discrimination, Grotius can find the philosophical material within his theory of public war to appeal to views that contradict his theory of public war. ${ }^{17}$ Inevitably, he produces a fundamentally incoherent theory.

\subsection{Walzer}

On its surface, Walzer's dualism can appear to be a product of a contradiction similar to Grotius'. Ultimately, however, Walzer's failings are closer to Vitoria's. Like both Vitoria and Grotius, Walzer at times describes the political community as a supraindividual body and the members as instruments of the body. Walzer describes war as analogous to, not reducible to, a relation between individuals (2006: 58). As he says, "[W]ar itself isn't a relation between persons but between political entities and their human instruments" (36).

\footnotetext{
${ }^{16}$ For a similar though much more developed exposition of this failure of Hobbes' theory, see Hampton (1986).

${ }^{17}$ Others have found a similar incoherence to Grotius' theory (see Tuck 1979: 79).
} 
Seen on one level, just wars for Walzer are based on the rights of political communities, or what he sometimes calls, peoples or nations. A community has a right to go to war when it is the victim of aggression. Aggression is defined as a violation of the rights of a political community to political independence and territorial integrity. To stop such rights violations it is worth sacrificing individual lives (53).

What makes political communities so valuable is their relation to what Walzer calls the "common life" of a people (54-7). Walzer describes this common life as a set of "shared experiences and cooperative activity." The common life is the particular cultural and political activities or norms that constitute a distinct political body. In this sense, then, just wars are fought between irreducibly social political entities and these entities are worth using individuals as violent instruments to protect.

However, like Grotius, Walzer claims that the rights of political communities are based on the rights of private individuals (53). He argues that the rights of states are derived from the private rights of their members through a social contract (54). This contract grounds the rights of political communities in war, including the right to conscript and sacrifice their members. In this way, the rights of political communities are not natural as they are for Vitoria and the classical theorists, but are derived, through contract, from the original rights of individuals to life and liberty. For Walzer, individuals can be transformed into violent instruments who are obligated to serve in war upon command regardless of the justice of the war through a social contract in a way that is consistent with original individual rights to life and liberty.

Grotius failed to show how this could be so and I confess that I don't think it is possible. In any case, it is worth noting that Walzer also seems to think that it cannot be done. In the only place in Just and Unjust Wars where Walzer speaks of the need to demonstrate how the duty to serve in war upon command can be derived from the rights of individuals to life and liberty he refers, in a footnote (54-5), to an earlier article of his, "The Obligation to Die for the State" (1970). In this article Walzer describes the sort of contract that he thinks could ground an obligation to die for the state. This "contract" turns out to require the creation of an essential connection between the individual and the political community such that the community is not merely an instrument for the protection of individual rights but is, rather, a supra-individual thing that the individual is essentially a part of. This essential connection between the individual and the community makes it the case that the destruction of the community is also the destruction of the individual even in cases where the individual physically survives the death of the community. For Walzer, prior to being obligated to die for the state one must cease being a private individual and become an ontological part of the state. Thus, when soldiers go to war, they act as, essentially, members of the political community. As he says, "They die willingly for the sake of the state, not because the state protects their lives - which would be...absurd-but because the state is their common life. So long as the state survives, something of the citizen lives on, even after the natural man is dead" (92).

In "The Obligation to Die for the State," as in Just and Unjust Wars, the "contract" that transforms individuals into members of the state is not a literal contract. It is described simply as the transformation, over time, of a private individual into a member of a common life. Indeed, in a later essay, Walzer (1998) denies that membership in a political community and the obligation to fight on its behalf is voluntarily assumed at all. Therefore, rather than being grounded in the private rights of individuals, the rights 
of public war appear to be grounded ultimately in the rights of political communities as such. Though Walzer asserts that, historically speaking, people were once private individuals with equal rights, his social "contract" simply refers to the subsequent transformation of people into members of political bodies. Thus, individuals do not "transfer" their original, private rights to the state. Rather, modern individuals find themselves, not as private, rights-bearing individuals, but as essentially political beings bound to serve a given state.

But, as we've seen, Walzer's theory of discrimination presupposes that the rights of individuals trump the rights of political communities. If the theory of discrimination is based on the rights of individuals, then it presupposes that the rights of individuals trump the rights of communities, including the political obligations of soldiers to obey. Rather than being obligated to obey orders regardless of their justice, according to the theory of discrimination, soldiers are obligated to refuse to obey orders that violate justice. According to the theory of discrimination, soldiers are responsible for the justice of their actions and are not the instruments of political communities.

To ground this understanding of the responsibilities of the soldier, Walzer must abandon the theory underpinning his jus ad bellum. Though at the level of jus ad bellum, soldiers confront each other as instruments of their communities, bound to obey their sovereign regardless of the justice of the war, Walzer describes the conduct of war, i.e., combat between soldiers on opposing sides, very differently. He conceives of combat as fundamentally and immediately a relation between equal, private individuals. On the battlefield, there occurs a direct interaction between individual men and women that is unmediated by any antecedent political obligations. In the conduct of war, men and women confront each other simply as men and women, as mere individual human beings with equal rights, not as obedient members of particular communities bound to obey.

This picture of combat emerges when Walzer discusses five firsthand accounts of combat experience wherein a combatant recounts a reluctance to attack an individual enemy soldier. On Walzer's interpretation, what underpins this reluctance to open fire on the enemy in all cases is the recognition of a fellow, equal human being in the enemy soldier. Walzer says that it is this understanding of combat that underpins his theory of jus in bello (2006: 142).

Thus, Walzer's dualism is derived from inconsistencies in the theory of justice underpinning his theory of just war. Regarding jus ad bellum, Walzer holds that the rights of communities are paramount and individuals are essentially connected to the community. Regarding jus in bello, Walzer holds that the rights of individuals are paramount and individuals are not essentially attached to the community. Thus, like Vitoria, Walzer's theory of public war is based on a communitarian theory of justice and his theory of discrimination is based on an individualist theory of justice.

\section{Explaining the Dualism}

We have seen that these seminal attempts at systematically defending a theory of just war share a similar failing. They each defend a theory of public war and a theory of discrimination that contain two incompatible views of the responsibilities of soldiers in war. According to the theory of public war, soldiers are not 
responsible for the justice of war. According to the theory of discrimination, soldiers are responsible for the justice of war.

Further, we have found that this dualism of responsibility reveals a fundamental incoherence in each of the theories. They are dualist all the way down. For Vitoria, the theory of public war is based on a quasi-Aristotelian theory of justice that holds the supra-individual political community is analogous to a natural body and its parts are ethically bound to serve its interests. Vitoria's theory of discrimination, however, treats the soldier as a private individual whose basic ethical task is to respect his and others' private rights.

For Grotius, the theory of public war is based on the idea of a social contract between essentially private persons who voluntarily form a public body and submit to the authority of a civil power who has the right to command them in war. But Grotius' social contract cannot accomplish this and he (at times) admits that soldiers are not the instruments of the civil power. Grotius' theory of discrimination appeals to this alternative understanding of the political obligations of subjects and denies that soldiers are obligated to obey commands in war, saying instead that they are responsible for the justice of the wars they participate in.

For Walzer, though he says that the theory of public war is based on a social contract between rights-bearing individuals who forfeit their rights to the political community and become its instrument, this is not the case. In fact, the basis of the soldier's duty to obey commands to serve in war is the ontological connection between the individual and the community that the individual did not voluntarily create. Walzer's theory of discrimination however is based on a view of the soldier as a private rights-bearing individual confronting other equal private rights-bearing individuals in combat.

How can we account for this structural deficiency in all three of these systematic just war theories? On my view, the dualism of modern just war theory is the result of failed attempts to overcome two philosophical challenges. The first is the apparent difficulty of grounding a principle of discrimination that is consistent with a theory of public war and acts as an independently binding side-constraint on public action in war. The second is the challenge of grounding a theory of public war in a modern individualism.

Regarding the first problem, the theory of public war presupposes that the political community is worth sacrificing individuals for. According to the theory of public war, individuals, even innocent individuals, may legitimately be killed for the sake of the rights of the community. On such theories, subjects are obligated to serve in war upon command. Thus, in a war between two commonwealths the soldiers who fight and die are often not personally committing any wrong even if they are participating in an unjust war. Their deaths are justified not because of anything they have done personally but because of the transcendent value of the political community. But if just cause for war justifies deliberately killing innocent people, then it is difficult to see why one should never deliberately kill noncombatants. According to the theory of public war, the innocence of noncombatants by itself cannot be a side-constraint on the pursuit of justice in war. Just cause for war could potentially justify unleashing any manner of violence on individuals, even innocent individuals, that is necessary to achieve the just cause.

Importantly, this could explain why the classical just war theorists did not develop theories of discrimination that acted as independent side constraints on public war. As Stephen Neff (2005: 64-5) argues, though classical theorists developed theories of 
discrimination that permitted attacking soldiers but prohibited attacking civilians, they based this distinction on necessity, not on a perceived intrinsic moral difference between soldiers and civilians. These theorists thought that one should not deliberately attack civilians because it was not necessary to achieve the just cause of the war. In principle, then, if it should become necessary to achieve the just cause, deliberate attacks on civilians would be permissible. For many, this is an unacceptably weak theory of discrimination.

Vitoria is usually credited with being one of the first in the Western tradition to attempt to ground a more robust theory of jus in bello, especially a principle of discrimination, that binds political communities in war independently of the justice of their cause thereby prohibiting deliberate attacks on civilians regardless of their military utility (see Johnson 1975: 195-203). But as we've seen, he does not ground his theory of discrimination in the same theory underpinning his theory of public war. Because he takes non-innocence to be the mark of those potentially liable to deliberate attack and views soldiers in an unjust war as non-innocents, he must contradict his theory of public war by denying that subjects are obligated to obey orders to participate in war. In denying that subjects are so obligated he seems to appeal to an individualist theory of private self-defense. This explains Vitoria's dualism. It reveals the challenges that advocates of public war, such as Grotius and Walzer, face in articulating a strong theory of discrimination. ${ }^{18}$

It should be noted that even if the theory of public war cannot be reconciled with a strong theory of discrimination it does not follow that there cannot be a coherent dualism of jus ad bellum/jus in bello as such. In principle, the theory of public war could be reconciled with the dualism of jus ad bellum/jus in bello. For instance, a political community could distribute responsibility for war in such a way that political leaders are solely responsible for the resort to war whereas soldiers are obligated to obey their leader's commands. At the same time, this community could delegate responsibility for the conduct of war to soldiers as well as their political leaders. This would amount to a coherent dualism of jus ad bellum/jus in bello. This being said, the point of this discussion has been to show that the content of the theory of jus in bello posited by conventional just war theory, particularly the principle of discrimination, contradicts the theory of public war. Vitoria, Grotius, and Walzer, while advocates of the theory of public war, attempt to prohibit deliberate attacks on noncombatants by appealing to positions that contradict their commitments regarding the responsibilities of soldiers entailed by the theory of public war. It is this move that creates the foundational dualism of modern just war theory, a dualism that in this case renders the theory incoherent.

The second problem is inherited from Grotius's individualist turn. The problem is that the theory of public war cannot straightforwardly be grounded in an individualist theory of justice. Grotius attempts to eschew the communitarian foundations of the classical theorists and replace them with a theory that holds the rights of private individuals are supreme. This project seems to successfully ground a theory of discrimination similar to Vitoria's. However, it fails to justify a theory of public war. The

\footnotetext{
${ }^{18}$ It also explains the turn to the voluntary law of nations as an independent ground for jus in bello constraints so clearly made by Vattel (2008 [1758]). This is where my dualism of just theory appears to connect with Stephen Neff's dualism mentioned above (see note 2).
} 
rights of individuals cannot be alienated to a political sovereign and all subjects must retain the obligation to not violate the rights individuals have prior to all contracts. Thus, Grotius cannot (and does not) consistently maintain that soldiers are obligated to obey orders to participate in war. Grotius' individualist turn thus undermines the theory of public war.

It is the apparent conflict between individualism and public war that ultimately explains Walzer's dualism as well. Walzer claims that his theory has an individualist basis. However, as we have seen, in order to justify public war, especially the duty of soldiers to serve in war upon command, he abandons his individualism and relies instead on a communitarian theory. But, like Vitoria, in order to ground a strong theory of discrimination Walzer must contradict his theory of public war and appeal to the rights of individuals instead. His just war theory thus relies on two inconsistent theories of justice in a manner similar to Vitoria.

This is why the dualism of just war theory revealed here is best thought of as a modern phenomenon. It is the product of a theory of just war with pre-modern origins coming into conflict with early modern individualism. This conflict appears first in attempts to ground a strong theory of discrimination alongside a traditional theory of public war and then in attempts to give modern foundations to the theory of public war.

Along with highlighting the need for a fundamental rethinking of the foundations of systematic just war theory, the story of the dualism of modern just war theory helps us understand the full significance of some recent revisionary trends in just war thought. Much of recent just war theory has accepted the individualism of modern just war theory embodied in the theory of discrimination but has, perhaps not entirely consciously, rejected the theory of public war (see Luban 1985; McMahan 2009; Fabre 2012; Frowe 2014). From the perspective adopted here, these recent theories can be understood as attempts to reduce just war theory to a modern theory of discrimination exemplified in Vitoria, Grotius, and Walzer. In effect, these recent theorists have chosen the discrimination strand of modern just war theory over the public war strand. We should now be in a better position to evaluate the merits and dangers of this revisionary trend.

\section{References}

Aquinas, T. (1997). The basic writings of Saint Thomas Aquinas. In A. C. Pegis (Ed.). Indianapolis: Hackett Publishing Company.

Aquinas, T. (2002). Aquinas: political writings. R. W. Dyson (Ed. and trans.). New York: Cambridge University Press.

Fabre, C. (2012). Cosmopolitan War. New York: Oxford University Press.

Frowe, H. (2014). Defensive Killing. New York: Oxford University Press.

Grotius, H. (2005 [1625]). In R. Tuck (Ed.), The rights of war and peace. Indianapolis: Liberty Fund, Inc.

Haakonssen, K. (1985). Hugo Grotius and the history of political thought. Political Theory, 13(2), $239-265$. Hampton, J. (1986). Hobbes and the social contract tradition. New York: Cambridge University Press. Hobbes, T. (1994 [1651]). Leviathan. E. Curley (Ed.). Indianapolis: Hackett Publishing Company. Johnson, J. T. (1975). Ideology, reason, and the limitation of war. Princeton: Princeton University Press. Luban, D. (1985). Just war and human rights. In C. Beitz et al. (Eds.), International ethics (pp. 195-216). Princeton: Princeton University Press.

Mapel, D. (1998). Coerced moral agents? Individual responsibility for military service. The Journal of Political Philosophy, 6(2), 171-189. 
McMahan, J. (1994). Innocence, self-defense, and killing in war. The Journal of Political Philosophy, 2(3), 193-221.

McMahan, J. (2009). Killing in war. New York: Oxford University Press.

McMahan, J. (2010a). The morality of war and the law of war. In D. Rodin \& H. Shue (Eds.), Just and unjust warriors: the moral and legal status of soldiers (pp. 19-43). New York: Oxford University Press.

McMahan, J. (2010b). Laws of war. In S. Besson \& J. Tasioulas (Eds.), The philosophy of international law (pp. 493-509). New York: Oxford University Press.

McPherson, L. (2004). Innocence and responsibility in war. Canadian Journal of Philosophy, 34(4), 485-506.

Neff, S. (2005). War and the law of nations. New York: Cambridge University Press.

Parsons, G. (2012). The Incoherence of Walzer's Just War Theory. Social Theory and Practice, 38(4), 663-88.

Parsons, G. (2013). What is the Classical Theory of Just Cause? A Response to Gregory Reichberg. Journal of Military Ethics, 12(4), 357-69.

Rodin, D. (2002). War and Self-Defense. New York: Oxford University Press.

Schneewind, J. B. (1998). The invention of autonomy. New York: Cambridge University Press.

Suarez, F. (2015 [1621]). A work on the three theological virtues. In T. Pink (Ed.), Selections from three works (pp. 829-989). Indianapolis: Liberty Fund, Inc.

Tadashi, T. (1993). Temperamenta (Moderation). In O. Yasuaki (Ed.), A normative approach to war: peace, war, and justice in Hugo Grotius. New York: Oxford University Press.

Tuck, R. (1979). Natural rights theories. New York: Cambridge University Press.

Tuck, R. (1999). The rights of war and peace. New York: Oxford University Press.

Vattel, E. (2008 [1758]). The law of nations. B. Kapossy and R. Whitmore (Eds.). Indianapolis: Liberty Fund, Inc.

Vitoria, F. (1991). Vitoria: political writings. A. Pagden and J. Lawrance (Eds. and trans.). New York: Cambridge University Press.

Walzer, M. (1970). The obligation to die for the state. In Obligations: essays on disobedience, war, and citizenship (pp. 77-98). Cambridge: Harvard University Press.

Walzer, M. (1983). Spheres of justice. New York: Basic Books.

Walzer, M. (1998). Involuntary association. In A. Gutmann (Ed.), Freedom of association (pp. 64-74). Princeton: Princeton University Press.

Walzer, M. (2004). Two kinds of military responsibility. In Arguing about war (pp. 23-32). New Haven: Yale University Press.

Walzer, M. (2006 [1977]). Just and unjust wars (4th ed.). New York: Basic Books. 